Vol-4, Issue-2, 2020 (IJEBAR)

E-ISSN: 2614-1280 P-ISSN 2622-4771

http://jurnal.stie-aas.ac.id/index.php/IJEBAR

\title{
"THE ROLE OF ORGANIZATIONAL CITIZENSHIP BEHAVIOR (OCB) TOWARDS GROWTH AND DEVELOPMENT OF THE COMPANY"
}

\author{
Helisia Margahana
}

STIE Trisna Negara Sumatera Selatan

Email : helisiagaraika87@gmail.com

\begin{abstract}
In a company, employees play a very strategic role and are the most valuable assets for the company's growth and development. Employee performance is getting better and has high loyalty if in a company there is a harmonious relationship between employees and the company. For this reason the company has an obligation to always pay attention to the welfare of all employees for the performance that has been given to the company. In carrying out the task, in reality there are a variety of behaviors that are caused by employees, especially if the employee is in a happy mood which in turn makes the company more effective, such behavior is helping colleagues, avoiding conflicts, participating in work groups, this behavior is called with the term Organizational Citizenship Behavior (OCB). This OCB will greatly benefit every company, because the company will become more effective and efficient. If the company has employees who behave OCB certainly the company will get better. For this reason, OCB has a very important role in the growth and development of the company.
\end{abstract}

Keywords : Role, Organizational Citizenship Behavior, Growth, Development.

\section{Introduction}

The quality of human resources (HR) plays an important role in the growth and development of a company. The company is expected to have qualified employees in order to win the competition between other companies in the business sector. The development of progress in the economic and technological fields can have a very large influence on the growth and progress of the company. That is why every company must immediately recognize these effects by making changes through improvements in the company in order to survive in the face of intense competition. Every company is demanded to be able to improve company performance in the most complete and most effective way, especially to improve the performance of individuals.

In a company the employee as a human resource has a very strategic role and is a valuable asset, that's why a company has an obligation to always maintain and pay attention to the welfare of all employees for the performance that has been given to the company. Employee performance will always be good and also has high loyalty, if the company and its employees can develop harmonious, mutually beneficial relationships. Employees are the driving force as the main factor in the progress of a business, which in carrying out their duties will certainly greatly affect the performance results. In carrying out the task, in reality there are various criteria in the form of behavior caused by employees, when employees in carrying out their 
duties feel happy, which in turn can make the company more effective. Employees who feel cared about by the company will also give kindness to the company. The quality of the relationship between superiors and subordinates will add a strong moral bond; will also affect the development of the company. Employees who are always happy in carrying out their tasks generally have a high social sense and are realized by helping each other employees, participating in work groups, encouraging other employees to consciously advance the company without harming other employees. This kind of employee behavior is known as Organizational Citizenship Behavior (OCB). Organizational Citizenship Behavior (OCB) can also be said to be an employee's readiness to take a role beyond his main duties in the company and is often also referred to as more behavior. This OCB will certainly be very beneficial for a company, because employees who have good behavior habits, run voluntarily, because it is not their main task, therefore Organizational Citizenship Behavior (OCB) is very beneficial for the company because it can lead to effectiveness, efficiency in a company. Employees who behave OCB can carry out anywhere, so there is no need to wait in a company to become large. If the company has OCB behavior, it can be ensured that the performance in the company will be good, when compared to companies that do not have OCB behavior. A successful company really requires the participation of all employees to do a good job for their company, that's why a strong company certainly needs employees who can do more work than what has been their job. Thus the Organizational Citizenship Behavior (OCB) plays an important role in the company's growth and development.

\section{Literature Review}

1) Role, has several definitions, including:

- Poerwadarminta, according to him, the role is an act carried out by an individual or group of people on an incident.

- Soerjono Soekamto stated that the role is a person's position to carry out his rights and obligations.

- Grass, Mason, according to him is a collection of desires aimed at individuals or groups in certain social groups.

So it can be concluded that the role implies an action carried out by a person or group of people on a particular event.

2) Organizational Citizenship Behavior (OCB) according to experts:

- Aldag and Resckhe, said that OCB is the participation of individuals carrying out work that exceeds their role in a workplace.

- Organization, according to him OCB is an individual act that is not bound, meaning that it is not directly related to the award that can be useful for the company.

- Golparvar and Javadian, OCB are voluntary acts that can be played by employees, and are not limited to their main work.

It can be concluded that Organizational Citizenship Behavior (OCB) is an act or behavior of an employee who voluntarily does something that is not his main task, but the act that is done makes it good for the company.

3) The growth and development of the company has the following meanings

- Company growth according to Suprantiningrum is an increase or decrease in all assets owned by the company. 
- While the company's development is a condition in a company that has increased from the previous situation in a certain period of time, the measure is the condition of the company's wealth.

\section{Research Method}

In a scientific research, the research method plays a very important role, because the research method is a series of scientific activities and is arranged systematically and has the aim of obtaining data to be used as intended. In this paper the research method used is literature review method to discuss the topic presented. The activities carried out in this literature study method include reading activities, studying library materials, searching and finding the results of research reports relating to the research carried out. The purpose of literature study is to solve problems that arise in critical and in-depth study of relevant library sources. This literature review is carried out by gathering information on various sources of literature used as a source of thought to generate new ideas and deduction from existing knowledge and new theories in the form of a framework can be developed. Literature review in a scientific research is a very important part of all activities in the research method.

In this writing the literature sources are obtained from research results, books, journals and related articles. While the steps taken in a library activity (Literature Review) are:

- Literature Review material, which is determined sources and aligned with the writing.

- Determination of library resources must be evaluated whether in accordance with the points to be loaded.

- A summary should be made of the specified library sources.

- Continue to explore new thoughts and ideas for further research material.

\section{DISCUSSION}

- Development of Organizational Citizenship Behavior (OCB)

During the last few years the development of Organizational Citizenship Behavior (OCB) has progressed rapidly, which was initiated by the research of experts who examined OCB problems in the company. Research on OCB by experts is influenced by social behavior in psychology especially the nature of employees who always prioritize the interests of others. Organizational Citizenship Behavior (OCB) history began around 1977 when Dennis Organ conducted a research to find out the answer to his curiosity. At that time the researchers believed employee satisfaction was very influential on productivity. But in reality there are not many real findings on this belief. Behavior characteristics that include OCB are helping colleagues, volunteering to do more work in the company, following applicable regulations, the nature of tolerance that is less pleasant in the workplace and using good time in the company, which is why OCB greatly increases the effectiveness, efficiency of a company.

OCB has several dimensions:

1) Behave often helps colleagues who have difficulty in carrying out tasks in the company (Altruism). 


\section{E-ISSN: 2614-1280 P-ISSN 2622-4771}

http://jurnal.stie-aas.ac.id/index.php/IJEBAR

2) Having a behavior that exceeds the minimum requirements of the company, for example, being present quickly in the company, using efficient working hours (Conscientiousness).

3) The company always behaves positively, does not complain and does not ask for something, because of the lack of good conditions in the company so it always tolerates the company (sportsmanship).

4) Behave involving yourself in organizational functions, for example, giving attention to an important meeting (courtesy).

5) Always follow developments in the company and store information and events in the company (civil virtue)

- Factors that influence Organizational Citizenship Behavior (OCB).

In its application, the Organizational Citizenship Behavior (OCB) of employees is based on internal and external factors.

Internal factors include:

1) Job Satisfaction

When an employee feels satisfied, the possibility of speaking positively is greater about his company, his co-workers are helped so as to make the work performance exceed the target achieved. Satisfied employees are also more obedient to call of duty. The base of job satisfaction is aspects of work which include wages, promotion opportunities and relationships with work colleagues.

2) Personality

Each individual's differences play an important role in showing his OCB to each company.

3) Organizational Commitment

Every employee basically has a desire to maintain himself in company membership, has a great desire to do the work in order to achieve company goals.

4) Employee Morals

It is a must or obligation for someone's decency to the company where he works.

5) Motivation

Namely the readiness of employees to carry out tasks in order to achieve company goals.

While external factors consist of:

1) Leadership Style

An activity or activity of a leader in influencing the activities of his subordinates to achieve the company's goals and objectives.

2) Organizational Culture

Is a collection of characteristics or characteristics that are valued by fellow employees in the company.

3) Trust in Leadership

Existence of trust that someone has towards others in this case the employee's trust in the leadership of the company. 
Vol-4, Issue-2, 2020 (IJEBAR)

\section{E-ISSN: 2614-1280 P-ISSN 2622-4771}

http://jurnal.stie-aas.ac.id/index.php/IJEBAR

- The role of Organizational Citizenship Behavior (OCB) in the company's growth and development

In today's competitive era, all companies are increasingly aware that by developing human resources (HR), a company will be able to grow and develop. So the main key to the company's progress is very dependent on the employees contained in the company, this means that a company really needs employee participation in achieving company goals. Without good employees, undoubtedly other resources can be mobilized; employees are the main driving force in a company. That is why employees really need Organizational Citizenship Behavior. OCB is very beneficial in a company, because OCB can make:

1) Manager productivity has increased.

2) Employees who behave extra in helping managers. Employees who have high manners will avoid coworkers' conflicts, and ultimately will help managers avoid a management crisis.

3) 2. The productivity of co-workers is better. Employees who like to help fellow workers will quickly help complete the tasks of their co-workers, which in turn can also increase the productivity of co-workers in a company.

4) 3. If employees help each other in the work, it can automatically save the manager and company resources, do the work do not need the intervention of managers and supervisors from the manager is relatively small, thus managers can use their time for other tasks.

5) Help save other resources, for example maintaining the cohesiveness of the group or team work, so that the time available can be more effective, because it does not take care of things that are less useful

6) As an effective means of coordinating group activities.

7) The company's ability to organize more increases in terms of retaining employees who excel, for example by giving other employees an example of not always complaining in work that ultimately fosters loyalty to the company.

8) Balance of company performance increases. Helping friends who do not come to work will improve the company's performance balance.

Thus a conclusion can be drawn that the Organizational Citizenship Behavior (OCB) is a voluntary behavior carried out by employees and is not an act that is forced to do and prioritizes company needs, this is the behavior of employees arising from job satisfaction and not being ruled and does not have direct connection with the reward system, meaning that voluntary acts are carried out by employees and do not ask for a reply in the form of money. One way to improve the Organizational Citizenship Behavior (OCB) of employees that the company can do is to make the company like a family, so that a company like a house where the residence is occupied feels comfortable for all employees in carrying out their duties. This method is the right way to do by every company, so that OCB employees can increase, because it will lead to employee job satisfaction. That is why it can be concluded that Organizational Citizenship Behavior (OCB) plays an important role in the company's growth and development.I 


\section{E-ISSN: 2614-1280 P-ISSN 2622-4771}

http://jurnal.stie-aas.ac.id/index.php/IJEBAR

\section{CONCLUSIONS AND SUGGESTIONS}

- Based on the results of the research and some literatures, the conclusions can be drawn:

1) Organizational Citizenship Behavior is an act or behavior of an employee who voluntarily does something that is not his main task, but the act that is done makes it good for the company.

2) The development of OCB began around 1977, when many researchers began to be interested in OCB in the company.

Behavior characteristics in OCB for example helping colleagues, following the applicable regulations, have a high tolerance for the state of the company.

3) Factors affecting OCB consist of internal factors which include:

- Job satisfaction

- Personality

- Organizational commitment

- Employee morale

- Motivation

While external factors consist of:

- Leadership style

- Organizational culture

- Trust in the leader

4) OCB is very beneficial for the company, because OCB can make manager productivity increase. The productivity of colleagues is better, the mutual help helps automatically save managers and company resources, helps save other resources because of groupings so that the time available can be more effective. Thus the Organizational Citizenship Behavior plays an important role in the company's growth and development.

- While the suggestions in this paper are:

1) It is recommended that every company can make the company like its own home, with the manager as head of the household and employees as family members, all of whom have their own responsibilities, so that each employee will feel comfortable working in the company. This is a good way to increase OCB in the company.

2) Employees should always be aware of their responsibilities in carrying out tasks within the company. We recommend that in recruiting employees, the manager must really consider the personality of the prospective employee, because many factors affect the emergence of Organizational Citizenship Behavior (OCB).

\section{References}

Aldag, R. \& Reschke, W. (1997). Employee value added: Measuring Discretionary Effort and its Value to the Organization. Center for Organization Effectiveness.

David Berry. 1995. Pokok-Pokok Pikiran dalam Sosiologi. Jakarta: PT Raja Grafindo Persada.

Golparvar dan Javadian. 2012.Structur Model of Psychological Contract,

Organization Commitment and Job 
Vol-4, Issue-2, 2020 (IJEBAR)

\section{E-ISSN: 2614-1280 P-ISSN 2622-4771}

http://jurnal.stie-aas.ac.id/index.php/IJEBAR

Satisfaction with Expectancy of the Organization and OCBs: Expectative Attitudes and Perception Model (EAPM). Iran: Islamic Azad University.

Organ, Dennis.W., Podsakof, Philip M., MacKenzie, B.S. 2006. Organizational

Citizenship Behavior. USA : Sage Publications.

Poerwadarminta, W.J.S. 1995. Kamus Umum Bahasa Indonesia.Jakarta: PT.Balai Pustaka.

Soekanto, Soerjono. 2002. Sosiologi Suatu pengantar. Jakarta : PT Raja Grafindo Persada.

Suprantiningrum. 2013. Pengaruh Moderasi Pengungkapan Corporate Social Responsibility (CSR) Terhadap Hubungan Return On Equity (ROE) dan Nilai Perusahaan. Jurnal Ilmiah UNTAG, Semarang.

Brahmasari, Ida Ayu. 2009. Organizational Citizenship Behavior (OCB) dan Isu Gender. Jurnal Ekonomi dan Manajemen. Vol. 5(2): 81.

Kusumajati, Dian Anggraini. 2014. Organizational Citizenship Behaviour (OCB)

Karyawan Pada Perusahaan. Journal of Character Building Development Center,

BINUS University Vol.5(1) 52-70

Margahana, Helisia; Siswoyo. 2018. The Effects of Job Motivation and Job Satisfaction Toward Organizational Citizenship Behavior (OCB) and Its Impact on Job Performance of Paramedical Community Health Centers in the City of Bandar Lampung. Journal of Resources Development and Management,

International Knowledge Sharing Platform, ISS. Vol. 46: 1-10. 